\title{
Dietary Habits and Cardiometabolic Health in Obese Children
}

\author{
Luisa Gilardini Marina Croci Lucia Pasqualinotto Katherine Caffetto \\ Cecilia Invitti \\ Department of Medical Sciences and Rehabilitation, Istituto Auxologico Italiano, Milan, Italy
}

\section{Key Words}

Dietary habits · Childhood obesity · Glucose metabolism · Hypertension · Cardiometabolic risk

\begin{abstract}
Background: Prevalence rates of cardiometabolic risk factors vary largely among overweight children. This study investigated the relationships between dietary habits and cardiometabolic health among obese children living in a city of Northern Italy. Methods: Dietary habits were collected in 448 obese subjects aged 6-18 years, attending an obesity outpatient center in Milan. Anthropometry, blood pressure (BP), lipids, fasting and post-load glucose, and insulin were measured. Physical activity was assessed in adolescents using a questionnaire. Results: Frequency of glucose intolerance, hypertension and dyslipidemia was $0.7 \%, 13 \%$ and $27.2 \%$, respectively. Plausible reporters consumed more animal protein and sodium and less legumes than recommended in nutritional recommendations and adequate amounts of fiber mainly derived from whole grains. Subjects skipping breakfast had unhealthy diets and greater body fatness. After adjustment for confounders, waist/height and fasting glucose were associated with sodium intake $(r=0.149$ and $r=0.142$, respectively; $p<0.05)$, 2-hour glucose with fiber $(r=-0.172 ; p<$ $0.01)$, and BP with vegetable protein intake (systolic $r=-0.120(p<0.05)$; diastolic $r=-0.267(p<$ $0.01)$ ). Hypertensive children consumed less vegetable protein than normotensive children. Conclusions: The cardiometabolic health of obese children improves with vegetable protein and whole grain intake, whereas dysglycemia and adiposity increase with sodium intake.
\end{abstract}

(c) 2015 S. Karger GmbH, Freiburg

\section{Introduction}

Prevalence of obesity has risen in the past three decades because of societal changes in eating habits and less active lifestyles, which shifted the balance of energy intake and expenditure [1]. Increased adiposity in childhood is associated with adverse cardiometabolic risk 
factors and diseases and is a predictor of significant morbidity in early adulthood [2]. However, prevalence rates and mean values of cardiometabolic risk factors vary largely among cohorts of overweight children worldwide depending on genetic and epigenetic causes [3]. For instance, the prevalence of dysglycemia among obese children referred to our obesity center has always been lower than in other cohorts of obese children and has not been associated with BMI [4-9]. Furthermore, we noticed that the frequency of dysglycemia progressively decreased in the last 10 years among obese children living in the Milan area in whom the frequency of impaired glucose tolerance (IGT) and type 2 diabetes was $0.5 \%$ and $0 \%$, respectively, in 2012 [10]. This minor prevalence of dysglycemia is lower than that recorded among other cohorts of white obese children where the prevalence of IGT and type 2 diabetes was reported to be $4.7-24.8 \%$ [6-9] and $0.4-13 \%[6,9]$, respectively. One of the reasons for this discrepancy may lie in eating habits.

Dietary factors as excessive consumption of saturated fats, cholesterol, and simple carbohydrates are believed to influence the development of cardiometabolic diseases [11, 12]; however, data in children are scarce and controversial [13], and the diet composition that should be recommended to prevent the cardiometabolic morbidity in obese children and adolescents has yet to be established [14-18].

This study was therefore designed to verify whether or not dietary habits may affect the cardiometabolic risk factors in obese children and adolescents.

\section{Participants and Methods}

\section{Subjects}

448 obese children and adolescents were recruited among those referred for a weight loss intervention to the obesity center of the Istituto Auxologico Italiano in Milan between 2005 and 2013. Assessment of obesity was based on the International Obesity Task Force definition of childhood obesity and quantified using BMI z-score which was calculated using Cole's least mean square method [19]. Patients with secondary obesity and binge eating disorders as well as those on any drug therapy were excluded from the study.

The study was approved by the Ethics Committee of our Institute, and informed consent was obtained from all subjects and their parents after a full explanation of the study.

\section{Clinical and Dietary Assessment}

Family history of obesity, diabetes, and cardiovascular diseases (hypertension, coronary artery disease, stroke in first- or second-degree relatives), and duration of overweight were assessed by questionnaires filled in by parents. Anthropometric measurements were taken as previously described [4]. Body composition was analyzed using bioimpedance analysis (BIA 101-RJL Systems Akern S.r.l., Pontassieve, Florence, Italy).

Dietary habits were collected by the same trained dietitian through interviews in the presence of children/adolescents and their mothers using the 7-day diet history method [20]. The interview consisted of three parts: one for food preparation and portion size at home; one for food intake and portion size at school by asking subjects their typical week's menu; and one for frequency and portion sizes of snacks consumed. Quantities were explored by means of food models, pictures, cups, and measures. Food energy and nutrient intake were calculated using a computerized database and analysis program (Dietosystem version 3.0; DS Medica S.r.l., Milan, Italy).

Office blood pressure (BP) was measured to the nearest $2 \mathrm{~mm} \mathrm{Hg}$ in the seated position three times after 5 min rest, using a standard mercury sphygmomanometer with an appropriately sized cuff on the nondominant arm. The average of measurements obtained on three different days was used in the analysis. Hypertension was defined as the occurrence of systolic or diastolic BP levels $\geq 95$ th percentile of height- and sex-adjusted reference levels [21].

A blood sample was drawn for the measurement of LDL- and HDL-cholesterol, triglycerides, uric acid, and alanine aminotransferase as well as of glucose and insulin during an oral glucose tolerance test.

High triglycerides were defined by plasma levels $\geq 100 \mathrm{mg} / \mathrm{dl}$ for children aged 7-9 years and $\geq 130$ $\mathrm{mg} / \mathrm{dl}$ for adolescents aged 10-19 years. High LDL-cholesterol was defined by plasma levels $\geq 130 \mathrm{mg} / \mathrm{dl}$, 
Gilardini et al.: Dietary Habits and Cardiometabolic Health in Obese Children

and low HDL-cholesterol was defined by plasma levels $<40 \mathrm{mg} / \mathrm{dl}$ [11]. Dyslipidemia was defined as the presence of high triglycerides and/or low HDL-cholesterol levels. Impaired fasting glucose (IFG), IGT, and type 2 diabetes were defined according to American Diabetes Association criteria [22]. In adolescents with plausible energy intake (EI) reports (see 'Statistical Analyses' below), the intensity of physical activity in the last 7 days was assessed using the International Physical Activity Questionnaire for Adolescents (IPAQ-A) which has been validated for assessing total physical activity and activities of different intensity in healthy European adolescents [23].

Biochemical Measurements

Plasma glucose, HDL- and LDL-cholesterol, triglycerides, uric acid, and alanine aminotransferase were measured using an automated analyzer (Roche Diagnostics, Mannheim, Germany). Serum insulin was measured by an Electrochemiluminescent assay (DPC, Los Angeles, CA, USA).

\section{Statistical Analyses}

Triglycerides and insulin that were not normally distributed were log transformed and expressed as median (interquartile range). Dietary EI plausibility was assessed using the ratio of EI to basal metabolic rate estimated using sex- and age-specific equations for weight and height [24]. Under-reporters were defined as subjects with EI/BMR $\leq 0.93$ for children aged 6-10 years and $\leq 1.1$ for older adolescents [25]. The analysis of covariance was used to establish the between groups differences. Group frequencies were compared using a chi-square test. The associations between dietary components and anthropometric and cardiometabolic variables were analyzed by partial correlation analysis. Data were expressed as mean \pm SD unless specified. A p $<0.05$ was considered statistically significant. All analyses were performed using SPSS version 21 (Statistical Package for Social Science Inc., Chicago, IL, USA).

\section{Results}

\section{Subjects Characteristics}

A total of 448 obese children and adolescents aged 7-18 years, were included in the study. Most (389) subjects were of Caucasian origin, and 59 of them belonged other ethnicity groups (Asian, Hispanic, and African). All subjects lived in the Milan area for more than 5 years. $72 \%$ of subjects provided plausible EI reports and were included in the analysis. Plausible reporters were younger, less obese, and more frequently female than underreporters. The ethnic composition and the proportion of hypertension, glucose intolerance, and dyslipidemia were similar in plausible and under-reporting subjects and in the whole group of 448 subjects originally recruited (table 1). Table 2 shows the clinical and biochemical characteristics of the 360 plausible reporters according to gender. Compared to girls, boys were younger, had higher BMI z scores, better body composition, and higher alanine aminotransferase and uric acid levels. Fasting glucose was higher in boys than in girls even after adjustment for age and BMI z score. Duration of obesity and family history of obesity, diabetes, and cardiovascular diseases did not influence the levels of cardiometabolic variables and the frequency of glucose intolerance, dyslipidemia, and hypertension (not shown).

\section{Dietary Habits}

The dietary composition of Caucasian and non-Caucasian obese children was similar, thus we conducted the analyses in the whole group of obese children. Table 3 shows dietary intakes according to gender. Energy intake was higher in boys than in girls. Obese children consumed more protein, mainly of animal origin, and more sodium than recommended by the Italian Recommended Dietary Allowances (RDAs) [26]. In this population, consumption of fiber and saturated fat complied with RDAs and that of soluble carbohydrates was slightly higher in girls only. 
Gilardini et al.: Dietary Habits and Cardiometabolic Health in Obese Children

Table 1. Clinical characteristics of 448 obese children and adolescents and of energy under-reporters and plausible reporters

\begin{tabular}{llll}
\hline & $\begin{array}{l}\text { Whole group } \\
(\mathrm{n}=448)\end{array}$ & $\begin{array}{l}\text { Plausible reporters } \\
(\mathrm{n}=360)\end{array}$ & $\begin{array}{l}\text { Under-reporters } \\
(\mathrm{n}=88)\end{array}$ \\
\hline Energy intake/basal metabolic rate & $1.4 \pm 0.3$ & $1.5 \pm 0.3$ & $0.9 \pm 0.1^{* *}$ \\
Non-Caucasian, \% & 13.1 & 13.1 & 13.0 \\
Age, years & $13.1 \pm 2.7$ & $12.8 \pm 2.8$ & $14.6 \pm 1.7^{* *}$ \\
Boys, \% & 38.2 & 35.8 & $47.7^{*}$ \\
BMI z-score & $3.2 \pm 0.7$ & $3.2 \pm 0.7$ & $3.0 \pm 0.7^{*}$ \\
Duration of obesity, years & $6.6 \pm 3.1$ & $6.5 \pm 3.1$ & $6.7 \pm 3.1$ \\
FH of obesity, \% & 71.3 & 70.0 & 78.0 \\
Hypertension, \% & 13.2 & 13.0 & 13.0 \\
IFG/IGT/DM2, \% & $1.1 / 0.7 / 0$ & $0.8 / 0.6 / 0$ & $2.4 / 1.2 / 0$ \\
Dyslipidemia, \% & 27.2 & 26.9 & 28.2
\end{tabular}

$\mathrm{FH}=$ family history; IFG = impaired fasting glucose; IGT = impaired glucose tolerance; DM2 = type 2 diabetes. ${ }^{*} \mathrm{p}<0.05$. ${ }^{* *} \mathrm{p}<0.0001$.

Table 2. Clinical characteristics of 360 obese plausible reporters according to gender

\begin{tabular}{lll}
\hline & $\begin{array}{l}\text { Boys } \\
(\mathrm{n}=129)\end{array}$ & $\begin{array}{l}\text { Girls } \\
(\mathrm{n}=231)\end{array}$ \\
\hline Age, years & $11.7 \pm 2.4$ & $13.4 \pm 2.8^{* * *}$ \\
FH of obesity,\% & 73 & 68 \\
FH of CVD, \% & 45 & 42 \\
FH of diabetes, \% & 62 & 58 \\
Duration of obesity, years & $6.5 \pm 3.1$ & $6.5 \pm 3.1$ \\
BMI $z$-score & $3.6 \pm 0.64$ & $2.9 \pm 0.60^{* *}$ \\
Waist/height, cm/cm & $0.62 \pm 0.06$ & $0.62 \pm 0.06$ \\
Fat mass, \% & $39.7 \pm 7.1$ & $42.5 \pm 5.1^{* * *}$ \\
Fat free mass, \% & $60.4 \pm 6.9$ & $57.4 \pm 5.3^{* * *}$ \\
Systolic BP, mm Hg & $109.5 \pm 14.0$ & $110.7 \pm 13.0$ \\
Diastolic BP, mm Hg & $70.6 \pm 8.1$ & $72.0 \pm 7.3$ \\
Heart rate, beats/min & $75.5 \pm 12.4$ & $75.0 \pm 12.3$ \\
Triglycerides, mg/dl & $66.0(47.2-93.0)$ & $73.0(57.0-97.0)^{*}$ \\
HDL-cholesterol, mg/dl & $48.9 \pm 10.4$ & $48.8 \pm 10.1$ \\
LDL-cholesterol, mg/dl & $92.0 \pm 24.5$ & $92.7 \pm 21.6$ \\
Fasting glucose, mg/dl & $84.5 \pm 5.8$ & $82.9 \pm 6.1^{* *}$ \\
2-hour glucose, mg/dl & $91.8 \pm 16.0$ & $88.2 \pm 15.0$ \\
Fasting insulin ${ }^{\mathrm{a}}, \mu \mathrm{H} / \mathrm{ml}$ & $12.0(7.7-17.3)$ & $13.6(9.8-18.0)$ \\
2-hour insulina, $\mu \mathrm{U} / \mathrm{ml}$ & $47.9(23.5-85.7)$ & $51.4(33.5-78.4)$ \\
Uric acid, mg/dl & $5.2 \pm 1.3$ & $4.7 \pm 0.9^{*}$ \\
ALT, U/l & $24.0 \pm 14.3$ & $18.6 \pm 10.6^{* *}$ \\
& &
\end{tabular}

$\mathrm{FH}=$ Family history; CVD = cardiovascular disease; $\mathrm{BP}=$ blood pressure; $\mathrm{HDL}=$ high-density lipoprotein; $\mathrm{LDL}=$ low-density lipoprotein; ALT = alanine aminotransferase. ${ }^{\text {aExpressed }}$ as median (interquartile range). ${ }^{*} \mathrm{p}<0.05 .{ }^{* *} \mathrm{p}<0.01 .{ }^{* *} \mathrm{p}<0.0001$. 
Gilardini et al.: Dietary Habits and Cardiometabolic Health in Obese Children

Table 3. Dietary composition of 360 obese plausible reporters according to gender

\begin{tabular}{|c|c|c|c|}
\hline & $\begin{array}{l}\text { Boys } \\
(n=129)\end{array}$ & $\begin{array}{l}\text { Girls } \\
(n=231)\end{array}$ & Italian RDAs $^{\mathrm{a}}$ \\
\hline Energy/day & $2,160.1 \pm 394.1$ & $1,986.1 \pm 375.6^{* * *}$ & - \\
\hline Total fat & & & $<30$ \\
\hline$\%$ energy & $29.7 \pm 4.8$ & $29.4 \pm 6.0$ & \\
\hline g/day & $71.2 \pm 21.1$ & $63.9 \pm 20.4^{* *}$ & \\
\hline Saturated fat & & & $<10$ \\
\hline \% energy & $8.6 \pm 2.1$ & $8.5 \pm 2.9$ & \\
\hline g/day & $20.7 \pm 8.4$ & $18.6 \pm 8.2^{*}$ & \\
\hline Monounsaturated fat & & & - \\
\hline$\%$ energy & $13.8 \pm 3.4$ & $13.6 \pm 4.0$ & \\
\hline g/day & $33.1 \pm 11.4$ & $29.8 \pm 10.7^{*}$ & \\
\hline Polyunsaturated fat & & & $>2.5$ \\
\hline$\%$ energy & $4.1 \pm 1.5$ & $3.9 \pm 1.4$ & \\
\hline g/day & $9.9 \pm 5.4$ & $8.6 \pm 4.1^{*}$ & \\
\hline Total protein & & & $<15$ \\
\hline$\%$ energy & $16.4 \pm 2.3$ & $16.9 \pm 2.5$ & \\
\hline g/day & $87.1 \pm 14.8$ & $82.4 \pm 14.9^{* *}$ & \\
\hline Animal protein & & & - \\
\hline \% energy & $8.8 \pm 2.4$ & $9.5 \pm 2.5^{* *}$ & \\
\hline g/day & $46.6 \pm 12.6$ & $46.1 \pm 12.3$ & \\
\hline Vegetable protein & & & - \\
\hline$\%$ energy & $7.1 \pm 1.5$ & $6.9 \pm 1.5$ & \\
\hline g/day & $37.5 \pm 8.6$ & $33.6 \pm 8.8^{* * *}$ & \\
\hline Animal/vegetable protein ratio & $1.3 \pm 0.5$ & $1.4 \pm 0.6^{*}$ & 1 \\
\hline Total carbohydrates & & & $<55$ \\
\hline$\%$ energy & $53.9 \pm 4.9$ & $53.6 \pm 5.7$ & \\
\hline g/day & $307.3 \pm 60.3$ & $279.9 \pm 60.2^{* * *}$ & \\
\hline Soluble carbohydrates & & & $<15$ \\
\hline$\%$ energy & $14.7 \pm 4.6$ & $15.1 \pm 4.5$ & \\
\hline g/day & $83.3 \pm 29.4$ & $77.6 \pm 24.5$ & \\
\hline Starch carbohydrates & & & - \\
\hline$\%$ energy & $34.5 \pm 6.7$ & $33.4 \pm 7.1$ & \\
\hline g/day & $195.6 \pm 51.0$ & $174.3 \pm 54.2^{* *}$ & \\
\hline Cholesterol & & & $<100$ \\
\hline mg/day & $227.0 \pm 81.0$ & $211.4 \pm 68.4$ & \\
\hline $\mathrm{mg} / 1,000 \mathrm{kcal} / \mathrm{day}$ & $107.2 \pm 40.2$ & $107.9 \pm 33.7$ & \\
\hline Fiber, g/day & $21.6 \pm 7.2$ & $21.4 \pm 8.5$ & $>(5+$ age $)$ \\
\hline \multicolumn{4}{|l|}{ Sodium, g/day } \\
\hline$\leq 10$ years & $1.42 \pm 0.49$ & $1.45 \pm 0.60$ & $<1.1$ \\
\hline$>10$ years & $1.78 \pm 0.74$ & $1.51 \pm 0.59^{*}$ & $<1.5$ \\
\hline
\end{tabular}

RDAs $=$ Recommended dietary allowances [26]. ${ }^{*} \mathrm{p}<0.05 .{ }^{* *} \mathrm{p}<0.001 .{ }^{* * *} \mathrm{p}<0.0001$.

Food consumptions in terms of categories are reported in table 4. Legume and fruit intakes were lower than those listed in the RDAs [26, 27].

$13 \%$ of children skipped breakfast. Compared to children who had breakfast, those skipping it had similar sex distribution, were older ( $13.5 \pm 2.6$ vs. $12.2 \pm 2.7$ years; $p<0.05)$, had higher age- and sex-adjusted waist/height ( $0.66 \pm 0.01$ vs. $0.62 \pm 0.01 ; \mathrm{p}<0.01)$, and consumed more salted snacks ( $0.5 \pm 0.5$ vs. $0.2 \pm 0.4$ serving/day; $\mathrm{p}<0.05)$ and seasoning fats ( $38.1 \pm 17.2$ vs. $25.2 \pm 10.6$ g/day; $p<0.001)$ as well as less cereals $(4.2 \pm 1.0$ vs. $5.2 \pm 1.2$ serving/day; $\mathrm{p}<0.01)$ and legumes $(1.2 \pm 2.7$ vs. $4.8 \pm 6.6 \mathrm{~g} /$ day; $\mathrm{p}<0.0001)$. 
Gilardini et al.: Dietary Habits and Cardiometabolic Health in Obese Children

Table 4. Average food group intake in 360 obese plausible reporters according to gender

\begin{tabular}{|c|c|c|c|}
\hline Food groups & $\begin{array}{l}\text { Boys } \\
(n=129)\end{array}$ & $\begin{array}{l}\text { Girls } \\
(n=231)\end{array}$ & Recommendations \\
\hline \multicolumn{4}{|l|}{ Pasta, rice, bread, pizza, cracker } \\
\hline Serving/day & $5.3 \pm 1.7$ & $4.9 \pm 1.2$ & \\
\hline g/day & $333.2 \pm 75.4$ & $291.3 \pm 111.1$ & \\
\hline Fruit & & & $>450 \mathrm{~g} /$ day $^{\mathrm{a}, \mathrm{b}}$ \\
\hline Serving/day & $1.6 \pm 1.1$ & $1.6 \pm 0.8$ & \\
\hline g/day & $315.4 \pm 211.1$ & $311.7 \pm 170.3$ & \\
\hline Vegetables & & & $>300$ g/day ${ }^{\mathrm{a}, \mathrm{b}}$ \\
\hline Serving/day & $1.6 \pm 0.7$ & $1.6 \pm 0.6$ & \\
\hline g/day & $281.0 \pm 123.9$ & $293.9 \pm 108.9$ & \\
\hline Legumes & & & $40 \mathrm{~g} /$ day $^{\mathrm{a}, \mathrm{b}}$ \\
\hline Serving/week & $0.5 \pm 0.8$ & $0.8 \pm 0.5$ & \\
\hline g/day (fresh) & $11.3 \pm 18.2$ & $14.5 \pm 19.9$ & \\
\hline Meat & & & 43-57 g/day ${ }^{\mathrm{a}, \mathrm{b}}$ \\
\hline Serving/week & $6.6 \pm 2.4$ & $6.6 \pm 2.1$ & \\
\hline g/day & $58.9 \pm 25.9$ & $63.5 \pm 22.1$ & \\
\hline \multicolumn{4}{|l|}{ Cold cuts, salami } \\
\hline Serving/week & $2.5 \pm 1.5$ & $2.2 \pm 1.2$ & \\
\hline g/day & $17.7 \pm 11.3$ & $15.6 \pm 8.3$ & \\
\hline \multicolumn{4}{|l|}{ Fish } \\
\hline Serving/week & $2.4 \pm 1.3$ & $2.8 \pm 1.4$ & \\
\hline g/day & $52.1 \pm 28.3$ & $61.3 \pm 29.1$ & \\
\hline \multicolumn{4}{|l|}{ Cheese } \\
\hline Serving/week & $2.7 \pm 2.0$ & $2.0 \pm 1.2^{*}$ & \\
\hline g/day & $38.8 \pm 29.3$ & $29.3 \pm 16.6^{*}$ & \\
\hline \multicolumn{4}{|l|}{ Eggs } \\
\hline Serving/week & $0.8 \pm 0.4$ & $0.8 \pm 0.5$ & \\
\hline g/day & $13.7 \pm 6.8$ & $13.7 \pm 8.5$ & \\
\hline Salted snacks, serving/day & $0.2 \pm 0.4$ & $0.3 \pm 0.5$ & \\
\hline Sweet products, serving/day & $0.6 \pm 0.6$ & $0.7 \pm 0.6$ & \\
\hline Sugar-sweetened beverages, serving/day & $0.3 \pm 0.4$ & $0.3 \pm 0.5$ & \\
\hline Seasoning fats, g/day & $26.6 \pm 11.3$ & $26.5 \pm 14.3$ & \\
\hline
\end{tabular}

${ }^{*} \mathrm{p}<0.05{ }^{\mathrm{a}, \mathrm{b}}$ Italian Recommended Dietary Allowances [26, 27]; raw weight.

\section{Physical Activity}

In the 196 plausible EI reporting adolescents (24\% males), the intensity of physical activity was assessed using IPAQ-A. Mean values of moderate activity, vigorous activity, and walking were $43.3 \pm 40.8 \mathrm{~min} /$ day, $11.5 \pm 14.5 \mathrm{~min} /$ day, and $28.6 \pm 35.5 \mathrm{~min} /$ day in boys and $24.7 \pm 24.1 \mathrm{~min} /$ day, $12.1 \pm 23.4 \mathrm{~min} /$ day, and $30.9 \pm 36.1 \mathrm{~min} /$ day in girls.

\section{Relationships between Dietary Habits, Adiposity and Cardiometabolic Variables}

In the partial correlation analysis after adjustment for age and sex, waist/height was correlated with BP (systolic BP r $=0.117$, diastolic BP $r=0.126 ; \mathrm{p}<0.05$ for both), lipids (HDLcholesterol $r=-0.218$, triglycerides $r=0.207 ; p<0.0001$ for both $)$ GPT $(r=0.179 ; p<0.0001)$ and insulin ( $r=0.303 ; p<0.0001)$, but not with fasting plasma glucose (FPG), 2-hour glucose, 2-hour insulin, and EI.

In the partial correlation analysis after adjustment for EI, age and sex, waist/height was positively associated with sodium intake ( $r=0.149$; $p<0.05)$, FPG with sodium consumption $(\mathrm{r}=0.142 ; \mathrm{p}<0.05)$, and 2-hour glucose with fiber consumption $(\mathrm{r}=-0.172 ; \mathrm{p}<0.01)$. After a further adjustment for waist/height, BP was negatively related to vegetable protein (systolic 
$\mathrm{r}=-0.120 ; \mathrm{p}<0.05$; diastolic $\mathrm{r}=-0.267 ; \mathrm{p}<0.01)$. Accordingly, vegetable protein intake was lower in hypertensive than in normotensive subjects ( $6.5 \pm 1.6$ vs. $7.1 \pm 1.5 \%$; $p<0.05$ ).

HDL-cholesterol was positively associated with fiber intake ( $r=0.117 ; p<0.05$ ); however, this relation disappeared after adjustment for saturated fat intake.

\section{Discussion}

This study demonstrates that cardiometabolic health of obese children living in the Milan area is affected by the intake of sodium, fiber, and vegetable protein. Compared to the Italian RDAs, dietary habits of this group of obese children were characterized by adequate consumption of energy, fiber, saturated fat and total carbohydrate but higher intake of sodium and animal protein. They were also consuming more fiber (21.5 vs. $13.5 \mathrm{~g} /$ day) and less fat (29.4 vs. 34.4-41.1\%) than obese children living in other regions of North, Center and South Italy $[28,29]$. Interestingly, the prevalence of IGT in obese children has been reported higher in these areas of Italy than in our cohort $[6,7,30]$. This finding together with the associations we found between fiber intake and 2-hour glucose suggests that fiber intake improves glucose homeostasis in obese children. This result is in accord with the reduction of postprandial glycemia observed after fiber supplements in obese children with abnormal glucose metabolism [31]. Dietary fiber in our cohort mainly derived from whole grains, supporting the results of longitudinal studies among adults which indicated an association between whole grain intake and reduced risk of type 2 diabetes and cardiovascular disease [32].

In this study, adiposity and FPG were adversely affected by sodium intake. Though an independent relationship between sodium intake and measures of adiposity has also been found previously in adolescents [33], the mechanism by which sodium increase adiposity is still unclear. Sodium intake has been shown to directly increase visceral adipogenesis in rats by stimulating the lipogenic enzymatic activity [34]. A potential adverse effect of dietary sodium on glucose levels is supported by a prospective study that reported an increased risk of type 2 diabetes in subjects with high urinary sodium excretion which was independently of obesity and hypertension [35]. The adverse effect of sodium intake on FPG does not seem mediated by a decrease in insulin sensitivity linked to adiposity because FPG levels were not associated with waist/height. This suggests that mechanisms possibly linked to increased inflammatory response [33] are responsible for the effects of sodium intake on glucose homeostasis. Obese children living in Milan area were found to consume high amounts of animal protein and low amounts of legumes. The consumption of animal protein, however, does not differ from that of the Italian general population of similar age [36]. Furthermore, the intake of animal protein had no relationships with any of the cardiometabolic variables, whereas that of vegetable protein was negatively associated with BP. This result corresponds to the inverse association of plant, but not animal, protein with BP observed in several crosssectional and prospective studies $[37,38]$. The mechanism by which plant protein decrease $\mathrm{BP}$ has been ascribed to the vasodilating properties of certain amino acids [39] but remains largely unknown and deserves further investigations.

A relatively low proportion of obese children living in the Milan area skipped breakfast. Breakfast consumption is known to limit weight gain by improving satiety and decreasing binge eating during the day [40]. As previously reported, skipping breakfast in our cohort was associated with greater body fatness. Children skipping breakfast consumed high amounts of salted snacks and seasoning fats and low amounts of legumes and whole grains, supporting the view that the relation between this attitude and obesity is mediated by a lower diet quality [41].

All levels of physical activity of obese adolescents were lower than those reported in adolescents of other European countries [23]. The inactivity in our cohort may play an 
important role in sustaining adiposity; however, this remains an assumption because levels of physical activity were not investigated in pre-adolescent children due to the lack of availability of a validated questionnaire for this age. On the other hand, an Italian survey reporting that children living in Milan are less active and play less frequently outdoors than the national average seems to further support our hypothesis [42].

The frequent family history of obesity presented by the obese children of our cohort suggests a possible genetic susceptibility to obesity.

In conclusion, cardiometabolic risk factors of obese children are worsened by sodium intake and low vegetable protein consumption and are improved by fiber intake.

\section{Disclosure Statement}

The authors declare no conflict of interest in the area.

\section{References}

1 May AL, Kuklina EV, Yoon PW: Prevalence of cardiovascular disease risk factors among US adolescents, 19992008. Pediatrics 2012;129:1035-1041.

- 2 Ng M, Fleming T, Robinson M, Thomson B, Graetz N, Margono C, Mullany EC, Biryukov S, Abbafati C, Abera SF, et al: Global, regional, and national prevalence of overweight and obesity in children and adults during 1980 2013: a systematic analysis for the Global Burden of Disease Study 2013. Lancet 2014;14:60460-68.

-3 van Vliet M, Heymans MW, von Rosenstiel IA, Brandjes DP, Beijnen JH, Diamant M: Cardiometabolic risk variables in overweight and obese children: a worldwide comparison. Cardiovasc Diabetol 2011;10:106-115.

4 Invitti C, Guzzaloni G, Gilardini L, P Morabito F, Viberti G: Prevalence and concomitants of glucose intolerance in European obese children and adolescents. Diabetes Care 2003;26:118-124.

5 Invitti C, Gilardini L, Pontiggia B, Morabito F, Mazzilli G, Viberti G: Period prevalence of abnormal glucose tolerance and cardiovascular risk factors among obese children attending an obesity centre in Italy. Nutr Metab Cardiovasc Dis 2006;16:256-262.

6 Brufani C, Ciampalini P, Grossi A, Fiori R, Fintini D, Tozzi A, Cappa M, Barbetti F: Glucose tolerance status in 510 children and adolescents attending an obesity clinic in Central Italy. Pediatr Diabetes 2010;11:47-54.

7 Morandi A, Maschio M, Marigliano M, Miraglia Del Giudice E, Moro B, Peverelli P, Maffeis C: Screening for impaired glucose tolerance in obese children and adolescents: a validation and implementation study. Pediatr Obes 2014;9:17-25.

-8 Körner A, Wiegand S, Hungele A, Tuschy S, Otto KP, l'Allemand-Jander D, Widhalm K, Kiess W, Holl RW; APV initiative; German Competence Net Obesity: Longitudinal multicenter analysis on the course of glucose metabolism in obese children. Int J Obes 2013;37:931-936.

-9 Michaliszyn SF, Mari A, Lee S, Bacha F, Tfayli H, Farchoukh L, Ferrannini E, Arslanian S: $\beta$-Cell function, incretin effect, and incretin hormones in obese youth along the span of glucose tolerance from normal to prediabetes to type 2 diabetes. Diabetes 2014;doi:10.2337/db 13-1951.

10 Gilardini L, Vallone L, Croci M, Pasqualinotto L, Caffetto K, Invitti C: L'attuale prevalenza di disglicemia nei giovani obesi residenti nella provincia di Milano è bassa ed influenzata da fattori epigenetici. Il Diabete 2012; 1(suppl 1):P274.

11 Fitch A, Fox C, Bauerly K, Gross A, Heim C, Judge-Dietz J, Kaufman T, Krych E, Kumar S, Landin D, Larson J, Leslie D, Martens N, Monagham-Beery N, Newell T, O’Connor P, Spaniol A, Thomas A, Webb B; Institute for Clinical System Improvement: Prevention and Management of Obesity for Children and Adolescents. 2013. www.icsi. org/_asset/tn5cd5/ObesityChildhood.pdf (last accessed March 3, 2015).

12 Saneei P, Hashemipour M, Kelishadi R, Rajaei S, Esmaillzadeh A: Effects of recommendations to follow the Dietary Approaches to Stop Hypertension (DASH) diet v. usual dietary advice on childhood metabolic syndrome: a randomised cross-over clinical trial. Br J Nutr 2013;110:2250-2259.

13 Prince RL, Kuk JL, Ambler KA, Dhaliwal J, Ball GD: Predictors of metabolically healthy obesity in children. Diabetes Care 2014;37:1462-1468.

14 Garemo M, Palsdottir V, Strandvik B: Metabolic markers in relation to nutrition and growth in healthy 4-y-old children in Sweden. Am J Clin Nutr 2006;84:1021-1026.

15 Vagstrand K, Forslund HB, Elfhag K, Linné Y, Rössner S, Lindroos AK: Eating habits in relation to body fatness and gender in adolescents - results from the 'SWEDES' study. Eur J Clin Nutr 2007;61:517-525.

16 Rodríguez G, Moreno LA: Is dietary intake able to explain differences in body fatness in children and adolescents? Nutr Metab Cardiovasc Dis 2006;16:294-301. 
Brauchla M, Juan W, Story J, Kranz S: Sources of dietary fiber and the association of fiber intake with childhood obesity risk (in 2-18 year olds) and diabetes risk of adolescents 12-18 year olds: NHANES 2003-2006. J Nutr Metab 2012;2012:736258.

18 Aburto NJ, Ziolkovska A, Hooper L, Elliott P, Cappuccio FP, Meerpohl JJ: Effect of lower sodium intake on health: systematic review and meta-analyses. BMJ 2013;346:1326-1346.

$\checkmark 19$ Cole TJ, Bellizzi MC, Flegal KM, Dietz WH: Establishing a standard definition for child overweight and obesity worldwide: international survey. BMJ 2000;320:1240-43.

20 Livingstone MB, Prentice AM, Coward WA, Strain JJ, Black AE, Davies PS, Stewart CM, McKenna PG, Whitehead RG: Validation of estimates of energy intake by weighed dietary record and diet history in children and adolescents. Am J Clin Nutr 1992;56:29-35.

-21 Lurbe E, Cifkova R, Cruickshank JK, Dillon MJ, Ferreira I, Invitti C, Kuznetsova T, Laurent S, Mancia G, MoralesOlivas F, Rascher W, Redon J, Schaefer F, Seeman T, Stergiou G, Wühl E, Zanchetti A; European Society of Hypertension: Management of high blood pressure in children and adolescents: recommendations of the European Society of Hypertension. J Hypertens 2009;27:1719-1742.

-22 American Diabetes Association: Diagnosis and classification of diabetes mellitus. Diabetes Care 2013;36(suppl 1):S67-74.

23 De Cocker K, Ottevaere C, Sjöström M, Moreno LA, Wärnberg J, Valtueña J, Manios Y, Dietrich S, Mauro B, Artero EG, Molnár D, Hagströmer M, Ruiz JR, Sarri K, Kafatos A, Gottrand F, De Henauw S, Maes L, De Bourdeaudhuij I; HELENA Study Group: Self-reported physical activity in European adolescents: results from the HELENA (Healthy Lifestyle in Europe by Nutrition in Adolescence) study. Public Health Nutr 2011;14:246-54.

24 Schofield WN: Predicting basal metabolic rate, new standards and review of previous work. Hum Nutr Clin Nutr 1985;39:5-41.

-25 Börnhorst C, Huybrechts I, Ahrens W, I Eiben G, Michels N, Pala V, Molnár D,Russo P, Barba G, Bel-Serrat S, Moreno LA, Papoutsou S, Veidebaum T, Loit HM,Lissner L, Pigeot I; DEFICS consortium: Prevalence and determinants of misreporting among European children in proxy-reported 24 h dietary recalls. Br J Nutr 2013;109: $1257-1265$

26 Revisione Documento di sintesi per il XXXV Congresso Nazionale SINU Bologna, 22 e 23 ottobre 2012. LARN e livelli di Assunzione di Riferimento di Nutrienti ed energia per la popolazione italiana. www.sinu.it/html/ cnt/larn.asp (last accessed March 3, 2015).

27 Società Italiana di Nutrizione Umana: Livelli di assunzione raccomandati di energia e nutrienti per la popolazione italiana (LARN). Rome, Istituto Nazionale della Nutrizione, 1996.

-28 Martone D, Roccaldo R, Censi L, Toti E, Catasta G, D’Addesa D, Carletti C; Z00 M8Study Group: Food consumption and nutrient intake in Italian school children: results of the Z00M8 study. Int J Food Sci Nutr 2013;64:700705.

29 Maffeis C, Maschio M, Costanzi S, Tommasi M, Fasan I, Morandi A: Diet macronutrient composition reported before treatment predicts BMI change in obese children: the role of lipids. Eur J Clin Nutr 2012;66:1066-1068.

-30 Valerio G, Licenziati MR, Iannuzzi A, Franzese A, Siani P, Riccardi G, Rubba P: Insulin resistance and impaired glucose tolerance in obese children and adolescents form Southern Italy. Nutr Metab Cardiovasc Dis 2006;16: 279-284.

-31 Moreno LA, Tresaco B, Bueno G, Fleta J, Rodríguez G, Garagorri JM, Bueno M: Psyllium fibre and the metabolic control of obese children and adolescents. J Physiol Biochem 2003;59:235-242.

-32 Ye EQ, Chacko SA, Chou EL,Kugizaki M, Liu S: Greater whole-grain intake is associated with lower risk of type 2 diabetes, cardiovascular disease, and weight gain J Nutr 2012;142:1304-1313.

33 Zhu H, Pollock NK, Kotak I, Gutin B, Wang X, Bhagatwala J, Parikh S, Harshfield GA, Dong Y: Dietary sodium, adiposity, and inflammation in healthy adolescents. Pediatrics 2014;133:635-642.

-34 Fonseca-Alaniz MH, Brito LC, Borges-Silva CN, Takada J, Andreotti S, Lima FB: High dietary sodium intake increases white adipose tissue mass and plasma leptin in rats. Obesity (Silver Spring) 2007;15:2200-2208.

-35 Hu G, Jousilahti P, Peltonen M, Lindström J, Tuomilehto J: Urinary sodium and potassium excretion and the risk of type 2 diabetes: a prospective study in Finland. Diabetologia 2005;48:1477-1483.

-36 Sette S, Le Donne C, Piccinelli R, Arcella D, Turrini A, Leclercq C; INRAN-SCAI 2005-6 Study Group: The third Italian National Food Consumption Survey, INRAN-SCAI 2005-06-part 1: nutrient intakes in Italy. Nutr Metab Cardiovasc Dis 2011;21:922-932.

-37 Tielemans SM, Altorf-van der Kuil W, Engberink MF, Brink EJ, van Baak MA, Bakker SJ, Geleijnse JM: Intake of total protein, plant protein and animal protein in relation to blood pressure: a meta-analysis of observational and intervention studies. J Hum Hypertens 2013;27:564-571.

-38 Tielemans SMAJ, Kromhout D, Altorf-van der Kuil W, Geleijnse JM: Associations of plant and animal protein intake with 5-year changes in blood pressure: the Zutphen Elderly Study. Nutr Metab Cardiovasc Dis 2014;24: 1228-1233.

39 Obarzanek E, Velletri PA, Cutler JA: Dietary protein and blood pressure. JAMA 1996;275:1598-1603.

-40 Tin SPP, Ho SY, Mak KH, Wan KL, Lam TH: Breakfast skipping and change in body mass index in young children. Int J Obesity 2011;35:899-906.

-41 Dubois L, Girard M, Potvin Kent M, Farmer A, Tatone-Tokuda F: Breakfast skipping is associated with differences in meal patterns, macronutrient intakes and overweight among pre-school children. Public Health Nutr 2009;12:19-28.

42 www.okkioallasalute.it (last accessed March 3, 2015). 